\title{
PEDAGOGIA DA AUTONOMIA: SABERES NECESSÁRIOS À PRÁTICA EDUCATIVA.
}

SILVA E ALVES, Luísa Helena ${ }^{1}$

\section{INTRODUÇÃO}

\begin{abstract}
$O$ respeito à autonomia e à dignidade de cada um é um imperativo ético e não um favor que podemos ou não conceder uns aos outros. (FREIRE, 1996, p.59)
\end{abstract}

O livro Pedagogia da Autonomia: saberes necessários à prática educativa, editado em 1996, por Paulo Freire, contém 146 páginas, publicado pela Editora Paz e Terra. Este livro está organizado em prefácio, primeiras palavras e três capítulos. O primeiro capítulo intitula-se Não há docência sem discência, o segundo Ensinar não é transferir conhecimento e o terceiro e último, Ensinar é uma especificidade humana. Cada capítulo é constituído de nove saberes essenciais e "obrigatórios" para a formação docente e reflexão da prática educativa-progressista.

No Prefácio, apresentado por Edna Castro Oliveira, salienta-se que as ideias retomadas no livro resgatam "de forma atualizada, leve, criativa, provocativa, corajosa e esperançosa" (FREIRE, 1996, p. 09), questões cotidianas que instigam o conflito e suscitam ao debate entre os educadores na sala de aula e também fora dela, desde a educação fundamental à pós-graduação. A solidariedade enquanto compromisso histórico, anunciada por Freire, é capaz de promover e instaurar a "ética universal do ser humano", que é exaustivamente retratada na obra.

Em Primeiras Palavras, Paulo Freire ressalta que a temática central da obra é a formação docente ao lado da reflexão sobre a prática educativo-progressista em favor da autonomia do ser dos educandos, e também a análise de saberes fundamentais a essa prática. $\mathrm{O}$ autor reitera que "formar é muito mais do que puramente treinar o educando no desempenho de destrezas" (FREIRE, 1996, p. 14), o qual critica também a política neoliberal vigente no terceiro mundo denominando-a de ideologia pós-modernista, fatalista e inflexível ao sonho e à utopia, admitindo-se que sua "legítima raiva" envolvida em seu discurso refere-se às injustiças aos denominados "esfarrapados do mundo". A responsabilidade ética no exercício da tarefa docente é ressaltada também como essencial aos docentes que se acham em formação para exercê-la, e jamais deve ser inseparável da prática educativa desde a educação para crianças, jovens e adultos. A ética universal é definida como inerente à natureza humana, indispensável à convivência social e permeia toda obra, sendo para Freire uma responsabilidade no exercício da docência. "[...] É que me acho absolutamente convencido da natureza ética da prática educativa, enquanto prática especificamente humana" (FREIRE, 1996, p.17).

No primeiro capítulo - Não há docência sem discência, o autor reconhece que ensinar não é transferir somente conhecimentos, mas criar as possibilidades para a sua produção ou a sua construção, afirmando que "Quem ensina aprende ao ensinar e quem aprende ensina ao aprender" (FREIRE, 1996, p.23). A docência e a discência desenvolvem a reciprocidade do conhecimento e da aprendizagem entre ambos os sujeitos da relação de ensino. A relação mútua de aprendizagem é contrária à educação bancária

\footnotetext{
${ }^{1}$ Instituto Federal do Triângulo Mineiro - IFTM
} 
alcunhada por Freire para referir-se como aquela em que ao discente é transferido o conteúdo, o conhecimento por um processo apassivador e autoritário, incapaz de despertar a curiosidade epistemológica. "[...] com relação a aprender, é um processo que pode deflagar no aprendiz uma curiosidade crescente, que pode torná-lo mais e mais criador" (FREIRE, 1996, p.24). Os saberes apresentados neste capítulo podem ser descritos como: ensinar exige rigorosidade metódica relacionada à criação, à instigação, à inquietude de educadores e educandos que vão se transformando em reais sujeitos da construção e reconstrução do saber; ensinar exige pesquisa que implica o compromisso com a consciência crítica do educando; ensinar exige respeito aos saberes dos educandos que são construídos na prática comunitária; ensinar exige criticidade que é o desenvolvimento da curiosidade crítica, insatisfeita e indócil; ensinar exige estética e ética em que a prática educativa seja um testemunho rigoroso de pureza e decência; ensinar exige a corporeificação das palavras pelo exemplo, no qual pensar certo é fazer certo; ensinar exige risco, aceitação do novo e rejeição a qualquer forma de discriminação tendo o pensar certo dialógico e não polêmico; ensinar exige reflexão crítica sobre a prática e como ressalta o autor, esse é o momento fundamental na formação permanente dos professores, e por último ensinar exige o reconhecimento e o acolhimento da identidade cultural de que fazem parte a dimensão individual e a classe dos educandos.

No segundo capítulo - Ensinar não é transferir conhecimento, o autor reafirma que ensinar não é transferir conhecimento do educador ao educando - ensino "bancário", mas criar as possibilidades para a sua própria produção ou a sua construção respeitando a autonomia, a dignidade e a identidade do educando. "[...] somos os únicos em quem aprender é uma aventura criadora, algo, por isso mesmo, muito mais rico do que meramente repetir a lição dada" [FREIRE, 1996, p.69]. A mera reprodução ou transferência de conteúdo torna o aprendiz mais "paciente" do que "sujeito crítico" de sua realidade. O autor apregoa que o papel primordial do docente é "contribuir positivamente para que o educando vá sendo o artífice de sua formação com a ajuda necessária do educador" [FREIRE, 1996, p.70]. Os saberes apresentados neste capítulo podem ser descritos como: ensinar exige consciência do inacabamento do ser humano e a necessária inserção do sujeito num permanente processo social de busca; ensinar exige o reconhecimento do ser condicionado ao meio social que se encontra, porém não significa que seja determinado por ele; ensinar exige respeito à autonomia do ser do educando e respeito ético para que os sujeitos dialógicos aprendam e cresçam na diferença; ensinar exige bom senso por quem educa, assim construído pela indagação, questionamento e reflexão à prática educativa; ensinar exige tolerância e luta em defesa direitos dos educadores como uma prática docente em que a luta possa ser reconhecida como uma categoria histórica; ensinar exige apreensão da realidade para nela intervir e recriar estabelecendo relação com o ensino dos conteúdos; ensinar exige alegria enquanto clima ou atmosfera do espaço pedagógico, e exige esperança de que professor e aluno juntos possam aprender, ensinar, inquietar, produzir; ensinar exige a conviç̧ão de que a mudança é possível e que não somos meramente objeto da História, mas seu sujeito, e, por último, ensinar exige curiosidade que convoca a imaginação, a intuição, as emoções, a capacidade de antever e comparar o objeto analisado.

No terceiro capítulo - Ensinar é uma especificidade humana, o autor clarifica que uma das qualidades essenciais que o docente deve apresentar em sua prática pedagógica é a segurança em si mesmo que o permite ter autoridade, exercida assim com sabedoria. "É a segurança que se expressa na firmeza com que atua, com que decide, com que respeita as liberdades, com que discute suas próprias posições, com que aceita rever-se" [FREIRE, 1996, p.91]. Freire salienta a necessidade do docente estar atento à leitura que é feita da atividade pelos educandos e acrescenta que "afinal, o espaço pedagógico é um texto para ser constantemente lido, interpretado, escrito e reescrito" [FREIRE, 1996, p. 97]. O comprometimento com o ensino passa pela atitude ética do docente e sua coerência na sala. "Tão 
importante quanto o ensino dos conteúdos é a minha coerência na classe. A coerência entre o que digo, o que escrevo e o que faço" [FREIRE, 1996, p. 102]. Os saberes apresentados neste capítulo podem ser descritos como: ensinar exige segurança, competência profissional como requisitos da formação do docente e generosidade manifestada no trato com os educandos; ensinar exige comprometimento do docente em sua atitude ética e com uma teoria e prática educativa condizente; ensinar exige compreender que a educação é uma forma de intervenção no mundo para reproduzir ou modificar a ideologia dominante; ensinar exige liberdade e autoridade que exigem o estabelecimento de limites para que não possam ser confundidas com licenciosidade e autoritarismo; ensinar exige tomada consciente de decisões a qual denominou de politicidade da educação; ensinar exige saber escutar com paciência e criticidade para aprender a falar com o educando; ensinar exige reconhecer que a educação é ideológica, e o pensar certo requer estar exposto às diferenças recusando posições dogmáticas; ensinar exige disponibilidade para o diálogo com respeito às diferenças provindas dos educandos e coerência entre o fazer/dizer do docente; ensinar exige querer bem aos educandos que engloba seriedade e afetividade docentes.

Freire ao encerrar o livro apresenta uma profunda reflexão da prática educativa como um exercício constante em favor da produção e do desenvolvimento da autonomia de educadores e educandos.

Portanto, a obra de Freire "Pedagogia da Autonomia" apresenta uma reflexão crítica quanto a teoria e prática do ensino na formação docente, bem como reafirma o valor da ética, do diálogo e da responsabilidade como imprescindíveis para educando e educador. Segundo o autor, ensinar é muito mais que uma profissão, é uma autêntica missão em que há um respeito profundo para com o educando e sua leitura de mundo, desenvolvendo-se assim seus conhecimentos, tornando-o consciente e mais autônomo perante o contexto em que atua.

O livro é recomendado a todos aqueles que se interessam por questões atinentes à educação, ética e cidadania. 